\title{
Kedudukan dan Pelaksanaan Fungsi Legislasi Dewan Perwakilan Daerah Pasca Putusan Mahkamah Kontitusi Nomor 79/PUU-XII/2014
}

\author{
Garciano Nirahua \\ Fakultas Hukum Universitas Pattimura, Ambon, Indonesia \\ E-mail: garciano_nirahua@yahoo.com
}

\begin{tabular}{l}
$\quad$ Dikirim: 07/06/2020 \\
\hline Info Artikel \\
Keywords: \\
The Status; \\
Legislation Function; \\
Local Representative \\
Council. \\
\\
\\
Kata Kunci: \\
Kedudukan; Fungsi \\
Legilasi; Dewan \\
Perwakilan Daerah. \\
\end{tabular}

\section{Abstract}

The Local Representative Council is one of barometers of reformation success in Indonesian state administration. as the Local Representative Council becomes a new legislative institution that will strengthen and work closely with previously-established legislative institutions (People's Representative Council). This study aims to: (1) find out and identify the status of legislation function of Local Representative Council based on the regulation after the decision of Constitutional Court; and (2) find out and identify the implementation of legislation function of Local Representative Council based on the regulation after the decision of Constitutional Court. The research method used normative research with a statute approach and a conceptual approach and analyzed descriptive qualitative. The results show that the constitutional authority of Indonesian Local Representative Council as a legislator institution is still very weak. Since the decision of Constitutional Court was read, from normative perspective, there is no any legislation change, either in planning, proposing, or discussing the regulation draft in the Indonesian Parliament, related to the authority of Indonesian Local Representative.

\begin{tabular}{l}
\hline Abstrak \\
DPD merupakan salah satu barometer keberhasilan reformasi dalam \\
bidang ketatanegaraan di Indonesia, dimana DPD menjadi lembaga \\
legislatif baru yang akan mendampingi dan memperkuat lembaga \\
legislatif yang telah lebih dulu dibentuk yaitu DPR. Penelitian ini \\
bertujuan (1) Untuk mengetahui dan mengidentifikasi kedudukan fungsi \\
legislasi Dewan Perwakilan Daerah berdasarkan peraturan perundang- \\
undangan Pasca Putusan Mahkamah Konstitusi, (2) Untuk mengetahui \\
dan mengidentifikasi pelaksanaan fungsi Legislasi DPD berdasarkan \\
peraturan perundang-undangan Pasca Putusan Mahkamah Konstitusi. \\
Metode penelitian menggunakan penelitian normatif dengan pendekatan \\
perundang-undangan (statute approach) dan pendekatan konseptual \\
(conceptual approach) serta dianalisis secara deskriptif kualitatif. Hasil
\end{tabular}


DOI:

10.47268/sasi.v26i3.309 penelitian menunjukkan bahwa kewenangan konstitusioanal DPD Republik Indonesia sebagai lembaga legislator dinilai masih sangat lemah, dimana sejak putusan Mahkamah Konstitusi dibacakan sampai sekarang, secara normatif belum ada proses perubahan legislasi baik dalam perencanaa, pengajuan, dan pembahasan Rancangan UndangUndang di DPR Republik Indonesia yang berkenaan dengan kewenangan DPD Republik Indonesia.

\section{A. PENDAHULUAN}

Dewan Perwakilan Daerah (DPD) merupakan salah satu barometer keberhasilan reformasi dalam bidang ketatanegaraan di Indonesia. Tentunya hal tersebut akan menjadi suatu hal yang baru, bukan hanya pada tatanan kelembagaan tetapi juga pada masyarakat Indonesia, dimana DPD menjadi lembaga legislatif baru yang akan mendampingi dan memperkuat lembaga legislatif yang telah lebih dulu dibentuk yaitu Dewan Perwakilan Rakyat (DPR). Pada dasarnya, kedua lembaga tersebut mempunyai garis perjuangan yang sama yaitu memperjuangkan aspirasi dan kepentingan rakyat dalam skala nasional dan daerah, ${ }^{1}$ dengan kata lain, keduanya adalah lembaga perwakilan namun mempunyai beberapa perbedaan baik dari segi fungsi, tugas dan wewenang, maupun dari segi proses rekruitmen keanggotaannya.

Ide awal dibalik perubahan ketiga UUD 1945, khususnya gagasan lahirnya DPD adalah, untuk mengubah sistem perwakilan menjadi sistem perwakilan dua kamar (bikameral) dan meningkatkan keikutsertaan daerah terhadap jalannya politik dan pengelolaan negara. ${ }^{2}$ Konsep ideal keberadaan DPD tersebut, pada awalnya juga bermaksud untuk mengakomodir prinsip perwakilan daerah dan pemberdayaan daerah. ${ }^{3}$

Perubahan ini terdapat dalam Pasal 2 ayat (1) UUD 1945 yang bunyinya:

"Majelis Permusyawaratan Rakyat terdiri atas anggota Dewan Perwakilan Rakyat dan anggota Dewan Perwakilan Daerah yang dipilih melalui pemilihan umum dan diatur lebih lanjut dengan undang-undang". Sebelumnya bunyi pasal ini adalah: "Majelis Permusyawaratan Rakyat terdiri atas anggota Dewan Perwakilan Rakyat ditambah utusan-utusan dari daerah-daerah dan golongan-golongan yang dipilih menurut aturan yang ditetapkan dengan undang-undang".

Perubahan terhadap ketentuan di atas berimplikasi pada reposisi peran Majelis Permusyawaratan Rakyat (MPR) dari lembaga tertinggi negara (supreme body) menjadi sebatas sidang gabungan (joint session) antara DPR dan DPD. MPR secara otomatis mengalami perubahan struktur keanggotaan yang di dalamnya terdiri dari anggota DPR dan anggota DPD yang dalam sistem ketatanegaraan modern disebut dengan sistem dua kamar (bikameral). ${ }^{4}$

1 Robert, E, R. (2005). Mengenal DPD-RI Sebuah Gambaran Awal, Jakarta: Institute For Local Development (ILD), h. 155.

2 Jumadi. (2019). "Penguatan Fungsi Pengawasan DPD RI Dalam Sistem Bikameral Parlemen". Jurisprudentie, 6 (1), h.101

3 Dermawan. Moh (2014). "Kedudukan Dewan Perwakilan Daerah dalam Kelembagaan Legerlatif Menurut UUD 1945”. Jurnal Ilmu Hukum Legal Opinion, 4 (2)

4 Marzuki, M. (2008). "Analisis Kontestasi Kelembagaan DPD dan Upaya Mengefektifkan Keberadaannya”, Jurnal Hukum, 1 (15), h. 84. 
Dalam sistem bikameral, masing-masing kamar mencerminkan jenis keterwakilan yang berbeda yaitu DPR merupakan representasi penduduk sedangkan DPD merupakan representasi wilayah (daerah). Perubahan yang terjadi dari sistem unikameral dengan supremasi MPR kepada sistem bikameral ini, menjadi sebuah keniscayaan karena selama ini Utusan Daerah dalam MPR tidak ikut membuat keputusan politik nasional dalam peringkat undang-undang. ${ }^{5}$

Pembentukan DPD semula dimaksudkan dalam rangka mereformasi struktur parlemen Indonesia menjadi dua kamar (bikameral) yang terdiri atas DPR dan DPD. DPR merupakan cermin representasi politik (political representation), sedangkan DPD mencerminkan prinsip representasi teritorial atau regional (regional representation). ${ }^{6}$

DPD sebagai lembaga perwakilan daerah di pusat, tentunya diharapkan mampu mempertahankan kepentingan daerah yang diwakilinya. Namun dalam proses memperjuangkan kepentingan rakyat dan daerah harus sesuai dengan konstitusi yang ada, yaitu pada Pasal 1 ayat (2) dan (3) UUD Negara RI 1945 yang bunyinya: "Kedaulatan berada di tangan rakyat dan dilaksanakan menurut Undang-Undang Dasar", dan "Negara Indonesia adalah negara hukum". Sehingga dari pasal tersebut menunjukkan bahwa sebesar apapun semangat DPD untuk memperjuangkan kepentingan daerahnya, tetaplah harus sesuai dengan ketentuan yang berlaku.

Perubahan Ketiga Undang-Undang Dasar Negara Republik Indonesia 1945 (selanjutnya disebut UUD NRI 1945) yang dilaksanakan pada tahun 2001 dalam Sidang Tahunan Majelis Permusyawaratan Rakyat Republik Indonesia, secara yuridis sebagai dasar kehadiran lembaga baru dalam sistem ketatanegaraan di Indonesia yaitu Dewan Perwakilan Daerah Republik Indonesia yang diatur dalam Pasal 22C dan Pasal 22D. Sebagai tindaklanjut dari Pasal 22C dan Pasal 22D UUD NKRI 1945, pengaturan dalam peraturan perundang-undangan yang berkaitan dengan DPD diatur dalam Undang-Undang Nomor 27 Tahun 2009 sebagaimana diubah dengan Undang-Undang Nomor 17 Tahun 2014 tentang Majelis Permusyawaratan Rakyat, Dewan Perwakilan Rakyat, Dewan Perwakilan Daerah dan Dewan Perwakilan Rakyat Rakyat Daerah. ${ }^{7}$

Kehadiran DPD sebagai lembaga baru hasil perubahan UUD NRI 1945 merupakan konsekuensi dari perubahan Pasal 1 ayat (2) sebagai upaya untuk mengoptimalkan dan meneguhkan paham kedaulatan rakyat. Hal ini terjadi karena paham kedaulatan rakyat selama ini melalui Majelis Permusyawaratan Rakyat (selanjutnya disebut MPR) sebagai pemegang kedaulatan rakyat telah disalahgunakan.

Perubahan Pasal 1 ayat (2) UUD NRI 1945 ini pun dengan sendirinya menegaskan bahwa MPR bukan satu-satunya yang melaksanakan kedaulatan rakyat. Rumusan Pasal 1 ayat (2) UUD NRI 1945 menyebutkan bahwa: "Kedaulatan adalah di tangan rakyat, dan dilakukan menurut Undang-Undang Dasar". 8

Rumusan tersebut di atas dimaksudkan bahwa kedaulatan rakyat yang pelaksanaannya diserahkan kepada badan/lembaga yang keberadaan, wewenang, tugas dan fungsinya ditentukan oleh UUD NRI 1945 itu serta bagian mana yang langsung dilaksanakan oleh Rakyat, dengan kata lain, pelaksanaan kedaulatan rakyat tidak diserahkan kepada

5 Asshiddiqie, J. (2006). “Perkembangan dan Konsolidasi Iembaga Negara Pasca Reformasi”, Jakarta: Konstitusi Press, h. 140

6 Asshiddiqie, J. (2010). Perkembangan dan Konsolidasi Lembaga Negara Pasca Reformasi, cet, pertama, Jakarta: Sinar Grafika, h. 119.

7 Neta, Y. (2011). "Upaya peningkatan peran Dewan Perwakilan Daerah (DPD) di Indonesia", Flat Justisia: Jurnal Ilmu Hukum, 5 (1), h. 93

8 Manan, B. (2004). Perkembangan Undang-Undang Dasar 1945, Yogyakarta: FH UII Press, h. 53 
badan/lembaga mana pun, tetapi langsung dilaksanakan oleh rakyat itu sendiri melalui pemilu. Implementasi dari prinsip kedaulatan rakyat di atas, maka dilakukan dalam bentuk pemilihan langsung bagi anggota DPD. ${ }^{9}$

Sampai pada saat ini DPD masih diharapkan sebagai penyambung lidah daerah secara serius maka, peran dan fungsi DPD mulai sekarang harus dioptimalkan. Jika kewenangan DPD hanya sifatnya konsultatif, maka fungsi cek and balance akan mandul karena terjadi monopoli kekuasaan legislasi. Imbas dari tidak adanya sistem cek and balance ini adalah tidak berjalannya pemberdayaan daerah. Daerah akhirnya tetap menjadi subordinat dalam sistem pembangunan nasional dan otonomi daerah pun hanya menjadi slogan belaka.

Berdasarkan uraian tersebut, maka penulis tertarik untuk menganalisis permasalahan mengenai pelaksanaan fungsi legislasi Dewan Perwakilan Daerah berdasarkan peraturan perundang-undangan Pasca Putusan Mahkamah Konstitusi

\section{B. METODE PENELITIAN}

Penelitian ini merupakan penelitian hukum normatif, yakni suatu penelitian yang terutama mengkaji ketentuan-ketentuan hukum positif, asas-asas hukum, prinsip-prinsip hukum maupun doktrin hukum guna menjawab isu hukum yang dihadapi. Pendekatan yang digunakan dalam penelitian ini adalah pendekatan peraturan perundang-undangan (statute approach), dan pendekatan konseptual (conceptual approach). ${ }^{10}$ Philipus M. Hadjon, lebih menyukai istilah "pengkajian ilmu hukum" dari istilah Belanda de beoefening van de rechtswetenscap atau het bedrijven van de rechswetenscap daripada penelitian hukum (legal research). Penelitian yang merupakan terjemahan dari bahasa Inggris research yang sering juga diterjemahkan menjadi kata riset, padanannya dalam bahasa Belanda adalah onderzoek karena penelitian hukum memiliki pemaknaan empiris, apalagi jika dikaitkan dengan definisi legal research yang dicirikan sebagai empiris, rasional, dan abstraktif. ${ }^{11}$

\section{PEMBAHASAN}

Dewan Perwakilan Daerah (DPD) hadir sebagai tuntutan reformasi melalui Perubahan UUD 1945 dalam konstruksi kekuasaan legislatif (legislative power) baru selain DPR. Pengaturan DPD dalam Pasal 22C dan Pasal 22D UUD 1945. Sebagai tindaklanjut dari Pasal 22C dan Pasal 22D ${ }^{12}$ UUD 1945, pengaturan dalam peraturan perundang-undangan yang berkaitan dengan DPD diatur dalam Undang-Undang Nomor 17 Tahun 20014 tentang Susunan dan Kedudukan Majelis Permusyawaratan Rakyat, Dewan Perwakilan Rakyat, Dewan Perwakilan Daerah, dan Dewan Perwakilan Rakyat Daerah sebagaimana telah diubah dengan Undang-Undang Nomor 42 Tahun 2014. Selain itu, implementasi DPD pun diatur dalam Undang-Undang Nomor 12 Tahun 2011 tentang Pembentukan Peraaturan Perundang-undangan.

UU MD2 tidak menguraikan kelembagaan DPRD sehingga bukan lagi sebagai lembaga negara yang diatur sejajar dengan MPR, DPR dan DPD dan UU P3, kewenangan

9 Panduan Pemasyarakatan Undang-Undang Dasar Negara Republik Indonesia Sesuai dengan Urutan Bab, Pasal, dan Ayat, Sekretariat Jenderal MPR RI, 2005, h. 44-45.

10 Ali, Z. (2009). Metode Penelitian Hukum, cet pertama, Jakarta: Sinar Grafika, h. 17.

11 Hadjon, P. M. (1997). Pengkajian Ilmu Hukum, Pelatihan Metode Penelitian Hukum Normatif, Pusat Penelitian Pengembangan Hukum, Lembaga Penelitian Universitas Airlangga, bekerja sama dengan Fakultas Hukum Universitas Airlangga, Surabaya, h. 6-7.

12 Riyanto, A. (2016), "Penataan Kewenangan Dewan Perwakilan Daerah Republik Indonesia menuju Strong Bicameralism”, Jurnal Cahaya Keadilan. 4 (2). h. 6 
legislatif DPD dibatasi dan DPD sekedar sebagai auxilliary state organ dari DPR. Walaupun DPD diatur secara jelas dalam Pasal 22C dan Pasal 22D UUD 1945 yang memiliki kewenangan legislasi, DPR sebagai pembentuk kedua undang-undang dimaksud tetap mereduksi kewenangan DPD sehingga tidak tercipta chechs and balances antara DPR dan DPD. Putusan Mahkamah Konstitusi dalam perkara nomor 79/PUU-XII/2014 terhadap UU MD2 dan UU P3 telah mengembalikan kewenangan legislasi DPD. Namun, DPR masih saja mengebiri kewenangan DPD walaupun telah merubah Undang-Undang Nomor 17 Tahun 2014 menjadi Undang-Undang Nomor 42 Tahun 2014, kewenangan legislasi DPD tetap tanpa adanya perubahan pasca putusan MK.

Penulisan ini lebih menyoroti sumber kewenangan DPD pasca putusan MK dan analisis terhadap konsep draft rancangan undang-undang, alam pemaparan hal-hal dimaksud, lebih ditonjolkan dasar kewenangan DPD sebagai lembaga negara utama (main state organ) dalam kekuasaan legislatif selain DPR. Berkaitan dengan konteks tersebut, maka penulis akan membahas lebih lanjut mengenai kewenangan legislasi Dewan Perwakilan Daerah (DPD) dan Putusan Mahkamah Konstitusi (MK) sebagai sumber kewenangan Dewan Perwakilan Daerah (DPD).

\section{Kewenangan Legislasi Dewan Perwakilan Daerah Republik Indonesia}

Dasar normatif pengaturan kewenangan konstitusional DPD diatur dalam Pasal 22D ayat (1), ayat (2), dan ayat (3) UUD 1945. Pasal 22D ayat (1), ayat (2), dan ayat (3) UUD 1945 menyebutkan bahwa:

a) Dewan Perwakilan Daerah dapat mengajukan kepada Dewan Perwakilan Rakyat rancangan undang-undang yang berkaitan dengan otonomi daerah, hubungan pusat dan daerah, pembentukan dan pemekaran serta penggabungan daerah, pengelolaan sumber daya alam dan sumber daya ekonomi lainnya, serta yang berkaitan dengan perimbangan keuangan pusat dan daerah.

b) Dewan Perwakilan Daerah ikut membahas rancangan undang-undang yang berkaitan dengan otonomi daerah; hubungan pusat dan daerah; pembentukan, pemekaran, dan penggabungan daerah; pengelolaan sumber daya alam dan sumber daya ekonomi lainnya, serta perimbangan keuangan pusat dan daerah; serta memberikan pertimbangan kepada Dewan Perwakilan Rakyat atas rancangan undang-undang anggaran pendapatan dan belanja negara dan rancangan undang-undang yang berkaitan dengan pajak, pendidikan, dan agama.

c) Dewan Perwakilan Daerah dapat melakukan pengawasan ${ }^{13}$ atas pelaksanaan undangundang mengenai : otonomi daerah, pembentukan, pemekaran dan penggabungan daerah, hubungan pusat dan daerah, pengelolaan sumber daya alam dan sumber daya ekonomi lainnya, pelaksanaan anggaran pendapatan dan belanja negara, pajak, pendidikan, dan agama serta menyampaikan hasil pengawasannya itu kepada Dewan Perwakilan.

Dari dasar pengaturan kewenangan konstitusional DPD, DPD memiliki 3 (tiga) fungsi, diantara fungsi legislasi, fungsi pertimbangan, dan fungsi pengawasan. Ketiga fungsi DPD ini bersifat terbatas, karena pelaksanaan fungsi-fungsi tersebut terbatas pada bidang-bidang tertentu saja yang menjadi kewenangan DPD. Bidang-bidang tertentu sebagai fungsi legislasi DPD lebih dominan merupakan artikulasi kepentingan daerah, antara lain otonomi daerah, pembentukan, pemekaran dan penggabungan daerah, hubungan pusat dan daerah,

13 Zada, K. (2013). "Kewenangan Legislasi Dewan Perwakilan Daerah Dalam Reformasi Kelembagaan Perwakilan Pasca Putusan Mahkamah Konstitusi”, Jurnal Cita Hukum, 3 (1), h, 29. 
pengelolaan sumber daya alam dan sumber daya ekonomi lainnya. Fungsi pertimbangan DPD berkaitan dengan pelaksanaan APBN, pajak, pendidikan dan agama. Fungsi legislasi dan fungsi pertimbangan DPD ini menjadi sumber adanya fungsi pengawasan DPD terhadap bidang-bidang dimaksud. ${ }^{14}$

Berkaitan dengan pelaksanaan fungsi DPD, maka yang menjadi persoalan adalah berkaitan dengan zelfstandigheid yaitu wewenang mandiri atau fungsi sepenuhnya dan atau fungsi yang menentukan dari lembaga perwakilan (DPD), baik dari segi perencanaan, penyusunan, pembahasan, sampai pengambilan keputusan. Hal ini dengan sendirinya berkaitan pula dengan kewenangan DPD dalam menjalankan fungsi legislasi, fungsi pertimbangan, dan fungsi pengawasan.

Ketentuan Pasal 22D UUD 1945 merupakan sumber konstitusional fungsi legislasi DPD dalam hal mengajukan rancangan undang-undang. Frasa "mengajukan kepada DPR" bermakna DPD sebagai lembaga utama pembentuk undang-undang (wetgever). Sebagai lembaga utama pembentuk undang-undang, posisi DPD seimbang dengan DPR sebagaimana diatur dalam Pasal 20 ayat (1) UUD 1945. ${ }^{15}$ Ketentuan ini berbeda dan tidak dapat disamakan dengan ketentuan Pasal 5 ayat (1) dan Pasal 20 ayat (2) sampai dengan ayat (4) UUD 1945 terkait dengan kedudukan Presiden sebagai medewetgever. Pelaksanaan kekuasaan legislatif, DPR dan DPD sebagai organ utama atau primer (primary constitutional organ), sedangkan Presiden merupakan organ pendukung atau penunjang (auxiliary state organ). Walaupun kewenangan DPD bersifat terbatas, DPD tidak berkedudukan sebagai medewetgever atau auxiliary state organ

\section{Putusan Mahkamah Konstitusi sebagai Sumber Kewenangan Dewan Perwakilan Daerah}

Putusan MK Nomor 79/PUU-XII/2014 dalam pengujian UU MD3 dan UU P3 secara umum menyatakan lima hal, antara lain: ${ }^{16}$

a. DPD terlibat dalam pembuatan program legislasi nasional (Prolegnas);

b. DPD berhak mengajukan RUU yang dimaksud dalam Pasal 22 D ayat (1) UUD 1945 sebagaimana hal nya atau bersama sama dengan DPR dan Presiden, termasuk dalam pembentukan RUU Pencabutan Peraturan Pemerintah Pengganti Undang-Undang;

c. DPD berhak membahas RUU secara penuh dalam konteks Pasal 22 D ayat (2) UUD 1945;

d. Pembahasan UU dalam konteks Pasal 22 D ayat (2) bersifat tiga pihak (tripartit), yaitu antara DPR, DPD, dan Presiden; dan

e. Mahkamah Konstitusi (MK) menyatakan bahwa ketentuan dalam UU MD3 dan UU P3 yang tidak sesuai dengan tafsir MK atas kewenangan DPD dengan sendirinya bertentangan dengan UUD 1945, baik yang diminta maupun tidak.

Putusan MK ini seyognya dijadikan sumber hukum dalam pembentukan RUU tentangan Perubahan Atas Undang-Undang Nomor 12 Tahun 2011 tentang Pembentukan Peraturan Perundang-undangan. Keberadaan putusan MK sebagai sumber hukum dan

14 Yuriska, (2010). "Kedudukan dan Fungsi Dewan Perwakilan Daerah (DPD) dalam Sistem Ketatanegaraan Indonesia", 2 (2), h. 54

15 Bidaya, J. (2012). "Kewenangan DPD Dalam Sistem Ketatanegaraan RI Menurut UUD 1945", Media Bina Ilmiah, 6 (6), h.12-13.

16 Hantoro, N. M. (2013). "Kewenangan Dewan Perwakilan Daerah Dalam Pembentukan UndangUndang Pasca Putusan Mahkamah Konstitusi Nomor 92/PUU-X/2012”, Jurnal Negara Hukum, 4 (2), URL : https://jurnal.dpr.go.id/, h. 198. 
kewenangan pembentukan peraturan perundang-undangan perlu dikaji untuk dijadikan sebagai sumber rujukan pembentukan suatu undang-undang.

Fakta pembentukan perundang-undangan pasca putusan MK Nomor 79/PUUXII/2014 belum sepenuhnya menjadi sumber hukum dalam perubahan UU MD3. DPR dalam pembentukan Undang-Undang Nomor 42 Tahun 2014 yang merevisi UndangUndang Nomor 17 Tahun 2014 tidak menjadikan putusan MK Nomor 79/PUU-XII/2014 sebagai sumber hukum.

Dalam teknis penyusunan peraturan perundang-undangan, Dictum "Dasar Hukum" harus memuat:

a. Dasar kewenangan pembentukan peraturan perundang-undangan, dan

b. Peraturan perundang-undangan yang memerintahkan pembentukan peraturan perundang-undangan.

Kedudukan putusan MK terkait dengan pengujian undang-undang (judicial review) memiliki kedudukan yang berbeda dengan putusan MK lainnya (sesuai kewenangan MK). Putusan MK dalam pengujian undang-undang merupakan pengujian terhadap norma hukum dan hasilnya melahirkan norma hukum baru. Hal ini berarti keberadaan putusan MK harus dijadikan sebagai landasan dasar hukum pembentukan peraturan perundang-undangan karena melalui putusan MK dimuat dasar kewenangan pembentukan peraturan perundangundangan.

Putusan MK secara umum menyatakan fungsi legislasi DPD dalam proses perencanaan, penyusunan, pembahasan, penetapan, dan penyebarluasan undang-undang. Secara teknis legislasi, norma hukum baru putusan MK harus diatur lagi dengan didasarkan pada putusan MK. Aspek perencanaan hingga penyebarluasan undang-undang sebagai kewenangan legislasi DPD perlu diatur untuk mencegah terjadinya kekosongan hukum.

\section{Pelaksanaan Fungsi Legislasi Dewan Perwakilan Daerah (DPD) Pasca Putusan Mahkamah Konstitusi}

Dewan Perwakilan Daerah Republik Indonesia (DPD RI) terwujud dengan semangat terwujudnya keadilan pembangunan dan terakomodirnya aspirasi masyarakat di daerah. Hal tersebutpun ditekankan dalam UUD Tahun 1945. DPD dalam hal ini merupakan lembaga non parpol yang menjaring aspirasi masyarakat di daerah. DPD merupakan hasil dari sebuah sistem perwakilan yang disebut dengan sistem bikameral ${ }^{17} /$ Second Chamber, di mana di negara asalnya bikameral/second chamber (dua kamar) adalah sistem yang mampu dalam menyerap serta melegislasikan aspirasi masyarakat daerah. ${ }^{18}$

Namun hal tersebut tampaknya tidak berjalan dengan semestinya, karena pada kenyataannya sistem keterwakilan di Indonesia bukanlah sistem bikameral murni. Hal tersebut tentu saja menjadi anomali sistem ketatanegaraan di Indonesia karena pembagian tugas dan kewenangan antara DPR dan DPD masih pada bayang-bayang ketidaksinkronan. Dalam hal ini tidak dipungkiri lemahnya peran DPD dikarenakan ketiadaan hak budgeting dan hak Interpelasi. Pada awalnya kedudukan DPD dengan DPR disejajarkan dengan fungsi

17 Hidayat, T (2015). "Penerapan sistem soft bikameral dalam parlemen di Indonesia”, JOM, 2 (2), h. $10-11$.

18 Andryan, Lubis, M. S, Suhaidi dan Nasution, F. A. (2013). "Penguatan Fungsi Legislasi Dewan Perwakilan Daerah dalam Sistem Ketatanegaraan Republik Indonesia (Analisis Putusan Mahkamah Konstitusi No. 92/PPU-X/2012)", USU - Law Journal, 3 (2), h. 165. 
DPR, tetapi pada perkembangannya terjadi evaluasi dan kurang mendapat pengawalan dari para pakar/ahli pemerintahan, sehingga terjadi abrasi kewenangan yang dimiliki DPD.

Penguatan peran DPD sangat penting untuk kemajuan di daerah-daerah seluruh Tanah Air Indonesia. Amandemen konstitusi sebagai salah satu cara yang paling penting untuk mengubah pola pembuatan undang-undang (legislasi) di parlemen, hal itu dimaksudkan agar DPD mempunyai kekuatan hukum sehingga keberadaan DPD sama pengaruhnya dengan DPR, karena DPD adalah penyeimbang DPR dalam segala hal-hal yang menyangkut peraturan kedaerahan. ${ }^{19}$

Pembentukan peraturan perundang-undangan yang mencakup tahapan perencanaan, penyusunan, pembahasan, pengesahan atau penetapan, dan pengundangan. Sementara peraturan perundang-undangan menurut Pasal 1 angka 2 Uundang-undang Pembentukan Peraturan Perundang-undangan adalah peraturan tertulis yang memuat norma hukum yang mengikat secara umum dan dibentuk atau ditetapkan oleh lembaga nagara atau pejabat yang berwenang melalui prosedur yang ditetapkan dalam peraturan perundang-undangan. Berkaitan dengan "Triparti" sebagaimana telah sampaikan oleh Anang Prihantoro, maka yang seharusnya terjadi sekarang ini ialah DPD, DPR dan Pemerintah sama-sama membahas RUU baik yang diusulkan DPD, DPR maupun Pemerintah. Kerena pasca putusan MK, DPD mempunyai kewenangan yang sama dengan DPR dan Pemerintah untuk membahas RUU secara Triparti (DPR, DPD dan Presiden). ${ }^{20}$

\section{PE N T U P}

Berdasarkan pembahasan di atas, maka dapat disimpulkan bahwa kedudukan DPD Putusan Mahkamah Konstitusi Nomor: 79/PUU-XII/2014, sejajar dengan DPR dan Pemerintah dalam pembahasan secara tripartit, namun kedudukan tersebut belum secara utuh terlaksana. berdasarkan kajian fungsi legislatif, dapat disimpulkan bahwa DPD RI mempunyai keterbatasan fungsi legislasi karena tidak mempunyai kekuasaan untuk membentuk undang-undang dan keberadaannya hanya sebagai "pembantu khusus" DPR RI dan pemerintah, atau dengan kata lain DPD RI hanyalah "weak chamber" di bawah DPR RI dan presiden dalam fungsi legislasi. Pelaksanaan fungsi DPD Pasca Putusan Mahkamah Konstitusi (MK) Nomor 79/PUU-XII/2014, fungsi legislasi DPD belum terlaksana secara menyeluruh. Hal ini disebabkan karena ada beberapa Pasal dalam UU MD3 yang belum mengakomodir isi Putusan MK.

\section{DAFTAR PUSTAKA}

\section{Jurnal}

[1] Lubis, A., Suhaidi, M. S., \& Nasution, F. A. (2013). Penguatan Fungsi Legislasi Dewan Perwakilan Daerah dalam Sistem Ketatanegaraan Republik Indonesia (Analisis Putusan Mahkamah Konstitusi No. 92/PPU-X/2012). USU - Law Journal, 3 (2).

[2] Bidaya, J. (2012). Kewenangan DPD Dalam Sistem Ketatanegaraan RI Menurut UUD 1945. Media Bina Ilmiah, 6 (6).

[3] Dermawan, M. (2014). Kedudukan Dewan Perwakilan Daerah dalam Kelembagaan

19 Hamdi, M. F. (2018). "Rekonstruksi Kedudukan Dewan Perwakilan Daerah Setelah Putusan Mahkamah Konstitusi No. 79/PUU-XII/2014”. Kanun, 20 (1), h. 195.

${ }^{20}$ Rudy, D. J. T dan Hadjon, E. T. L. (2018). "Implikasi dari Putusan Mahkamah Konstitusi Nomor 92/PUU-X/2012 Dalam Kaitannya Dengan Tugas Fungsi dan Kewenangan DPD”. Kertha Negara, 06 (03), h. 4. 
Legerlatif Menurut UUD 1945. Jurnal Ilmu Hukum Legal Opinion, 4 (2).

[4] Hamdi, M. F. (2018). Rekonstruksi Kedudukan Dewan Perwakilan Daerah Setelah Putusan Mahkamah Konstitusi No. 79/PUU-XII/2014. Kanun, 20 (1).

[5] Hantoro, N. M. (2013). Kewenangan Dewan Perwakilan Daerah dalam Pembentukan Undang-Undang Pasca Putusan Mahkamah Konstitusi Nomor 92/PUU-X/2012. Jurnal Negara Hukum, 4 (2).

[6] Hidayat, T. (2015). Penerapan sistem soft bikameral dalam Parlemen di Indonesia", JOM, 2 (2).

[7] Jumadi. (2019). Penguatan Fungsi Pengawasan DPD RI Dalam Sistem Bikameral Parlemen. Jurisprudentie, (6) 1.

[8] Marzuki, M. (2018). Analisis Kontestasi Kelembagaan DPD Dan Upaya Mengefektifkan Keberadaannya. Jurnal Hukum, 1 (15).

[9] Neta, Y. (2011). Upaya peningkatan peran Dewan Perwakilan Daerah (DPD) di Indonesia. Flat Justisia: Jurnal Ilmu Hukum, 5 (1).

[10]Riyanto, A. (2016). Penataan Kewenangan Dewan Perwakilan Daerah Republik Indonesia menuju Strong Bicameralism. Jurnal Cahaya Keadilan, 4 (2).

[11] Rudy, D. J. T., \& Hadjon, E. T. L. (2018). Implikasi dari Putusan Mahkamah Konstitusi Nomor 92/PUU-X/2012 Dalam Kaitannya Dengan Tugas Fungsi dan Kewenangan DPD. Kertha Negara, 06 (03).

[12]Pasaribu, P. (2017). Kedudukan dan fungsi Dewan Perwakilan Daerah (DPD) dalam Sistem Ketatanegaraan Indonesia, Yuriska : Jurnal Ilmiah Hukum, 2 (2).

[13]Zada, K. (2013). Kewenangan Legislasi Dewan Perwakilan Daerah Dalam Reformasi Kelembagaan Perwakilan Pasca Putusan Mahkamah Konstitusi, Jurnal Cita Hukum, 3 (1).

\section{Buku}

[14] Ali, Z. (2009). Metode Penelitian Hukum, cet pertama, Jakarta: Sinar Grafika.

[15] Asshiddiqie, J. (2006). Perkembangan dan Konsolidasi Iembaga Negara Pasca Reformasi, Jakarta: Konstitusi Press.

[16] Asshiddiqie, J. (2010). Perkembangan dan Konsolidasi Lembaga Negara Pasca Reformasi, Jakarta: Sinar Grafika,

[17] Hadjon, P. M.. (2009). Argumentasi Hukum, Gadjah Mada University Press, Yogyakarta

[18] Manan, B. (2004). Perkembangan Undang-Undang Dasar 1945, FH UII Press: Yogyakarta

[19] Robert, E, R. (2005). Mengenal DPD-RI Sebuah Gambaran Awal, Jakarta: Institute For Local Development.

\section{Lain-Lain}

[20]Hadjon, P. M. (1997). Pengkajian Ilmu Hukum, Pelatihan Metode Penelitian Hukum Normatif, Pusat Penelitian Pengembangan Hukum, Lembaga Penelitian Universitas Airlangga, bekerja sama dengan Fakultas Hukum Universitas Airlangga, Surabaya.

[21]Panduan Pemasyarakatan Undang-Undang Dasar Negara Republik Indonesia Sesuai dengan Urutan Bab, Pasal, dan Ayat, Sekretariat Jenderal MPR RI, 2005. 